Swarthmore College

Works

6-1-2011

\title{
Stress-Dependent Impairment Of Passive-Avoidance Memory By Propranolol Or Naloxone
}

\author{
Allen M. Schneider \\ Swarthmore College, aschnei1@swarthmore.edu \\ Peter E. Simson , '78 \\ Ranga Keshani Atapattu , '08 \\ Lynn G. Kirby , '89
}

Follow this and additional works at: https://works.swarthmore.edu/fac-psychology

Part of the Psychology Commons

Let us know how access to these works benefits you

\section{Recommended Citation}

Allen M. Schneider; Peter E. Simson , '78; Ranga Keshani Atapattu , '08; and Lynn G. Kirby , '89. (2011). "Stress-Dependent Impairment Of Passive-Avoidance Memory By Propranolol Or Naloxone". Pharmacology Biochemistry And Behavior. Volume 98, Issue 4. 539-543. DOI: 10.1016/j.pbb.2011.03.005 https://works.swarthmore.edu/fac-psychology/97 


\title{
Stress-dependent impairment of passive-avoidance memory by propranolol or naloxone
}

\author{
Allen M. Schneidera, ${ }^{a}$, Peter E. Simson ${ }^{b}$, Ranga K. Atapattua ${ }^{a}$, and Lynn G. Kirbyc \\ aDepartment of Psychology, Swarthmore College, Swarthmore, PA 19081, United States \\ ${ }^{b}$ Department of Psychology and Center for Neuroscience, Miami University, Oxford, $\mathrm{OH} 45056$, \\ United States \\ 'Department of Anatomy \& Cell Biology and Center for Substance Abuse Research, Temple \\ University School of Medicine, Philadelphia, PA 19140, United States
}

\begin{abstract}
Previous work has shown that the effect of opioid-receptor blockade on memory modulation is critically dependent upon the intensity of stress. The current study determined the effect of adrenergic-receptor blockade on memory modulation under varied levels of stress and then compared the effect of adrenergic-receptor blockade under intense stress to that of a) opioidreceptor blockade and b) concurrent opioid- and adrenergic-receptor blockade. In the first experiment, the $\beta$-adrenergic-receptor blocker propranolol impaired retention in the passiveavoidance procedure when administered immediately after exposure to intense stress (passiveavoidance training followed by swim stress) but not mild stress (passive-avoidance training alone). In the second experiment, while separate administration of either propranolol or the opioidreceptor blocker naloxone immediately after exposure to intense stress impaired retention, the combined administration of propranolol and naloxone failed to do so. These findings demonstrate that the effect of $\beta$-adrenergic-receptor blockade or opioid-receptor blockade on memory modulation in the passive-avoidance procedure is dependent upon the intensity of stress, and suggest that concurrent inactivation of endogenous adrenergic- and opioid-based memory modulation systems under stressful conditions is protective of memory.
\end{abstract}

\section{Keywords}

Propranolol; Naloxone; Forced swim; Passive-avoidance training; Stress; Memory modulation

\section{Introduction}

Evidence that an adrenergic-mediated system modulates memory under stressful conditions comes primarily from studies in which adrenergic agonists, administered shortly after passive-avoidance training, enhance retention (Ferry et al., 1999; Ferry and McGaugh, 2008; Liang et al., 1986, 1990). Less consistent are the results of studies investigating the effect on memory modulation of adrenergic blockers; for example, the $\beta$-adrenergic antagonist propranolol, administered systemically shortly after training, impairs retention in a spatial water maze (Cahill et al., 2000) but fails to impair retention in a passive-avoidance procedure (Decker et al., 1990; McGaugh, 1989; Saha et al., 1991). Immersion in water that accompanies spatial water maze learning, however, is extremely stressful and markedly

(C) 2011 Elsevier Inc. All rights reserved.

"Corresponding author. Tel.: +1 610328 8420; fax: +1 610328 7814. ASchnei1 @ Swarthmore.edu (A.M. Schneider). 
activates the endogenous adrenergic system (Cahill et al., 2000; Mabry et al., 1995). Consequently, a possible explanation for these conflicting results is that the intensity of stress from immersion in water (that accompanies spatial water maze learning) is greater than that of stress from mild footshock (used in passive-avoidance training), suggesting that the effectiveness of $\beta$-adrenergic receptor blockade in impairing retention depends on the level of stress (and thus the degree of stress-induced adrenergic system activation) that accompanies its administration. This hypothesis was tested in the first experiment by determining if propranolol impairs retention in the passive-avoidance procedure when animals are exposed to an additional stressor (forced swim) known to activate memory modulation systems, including the endogenous adrenergic system (Gotoh et al., 1998; Jordan et al., 1994), subsequent to passive-avoidance training.

A similar hypothesis has previously been tested regarding the effect on retention of blockade of another stress-related memory-modulation system, the opioid system (Schneider et al., 2009). The findings indicated that the effectiveness of opioid-receptor blockade in impairing retention depended on intensity of stress. Consequently, in the second experiment, the effect of pharmacological blockade of the adrenergic system on retention under highly stressful conditions was compared to that of blockade of the opioid system, while the potential interaction between the two memory modulation systems was investigated through concurrent $\beta$-adrenergic receptor and opioid-receptor blockade.

\section{Material and methods}

\subsection{Subjects}

The subjects $(\mathrm{n}=69)$ were male Long-Evans hooded rats weighing $240-280 \mathrm{~g}$ at the start of the experiment. The rats were housed two to a cage with access to food and water ad libitum. The colony room was maintained at $20^{\circ} \mathrm{C}$ and was illuminated on a 12 -h light-dark cycle (lights on at 9:00 a.m.). All experiments were conducted between 10:00 a.m. and 12:00 p.m. The experimental protocol was approved by Swarthmore College's Institutional Animal Care and Use Committee and was in compliance with the National Research Council Guide for the Care and Use of Laboratory Animals.

\subsection{Apparatus}

The rats were trained in a standard trough-shaped passive-avoidance apparatus that consisted of a small lighted compartment $(20 \mathrm{~W} \times 28 \mathrm{H} \times 18 \mathrm{~L} \mathrm{~cm}$ at the top; $8 \mathrm{~W} \times 28 \mathrm{H} \times 18 \mathrm{~L} \mathrm{~cm}$ at the base), illuminated by a $95-\mathrm{W}$ bulb, connected to a larger dark compartment $(20 \mathrm{~W} \times 28$ $\mathrm{H} \times 42 \mathrm{~L} \mathrm{~cm}$ at the top; $8 \mathrm{~W} \times 28 \mathrm{H} \times 42 \mathrm{~L} \mathrm{~cm}$ at the base). A manually operated sliding door separated the two compartments. The top of each compartment was hinged and the floor of each compartment was made of stainless steel plates. A constant-current Lafayette Master Shocker (Model 2400SS; Lafayette, IN) was connected to the floor of the large compartment. The apparatus was located in a quiet, dimly illuminated room.

\subsection{Drug administration and drug doses}

The rats were injected intraperitoneally with vehicle $(0.9 \%$ saline, $2 \mathrm{ml} / \mathrm{kg})$, the $\beta$-adrenergic antagonist dl-propranolol hydrochloride ( $10 \mathrm{mg} / \mathrm{kg}, 2 \mathrm{ml} / \mathrm{kg}$, Sigma Chemical), the opioid antagonist naloxone hydrochloride ( $3 \mathrm{mg} / \mathrm{kg}, 2 \mathrm{ml} / \mathrm{kg}$, Sigma Chemical) or a mixture of propranolol $(10 \mathrm{mg} / \mathrm{kg})$ and naloxone $(3 \mathrm{mg} / \mathrm{kg})$ in a $2 \mathrm{ml} / \mathrm{kg}$ injection volume. The dose of propranolol chosen was similar to doses that have previously been shown to be effective in adrenergic studies on memory modulation (Cahill et al., 2000; Przybyslawski et al., 1999). The dose of naloxone has been used in previous passive-avoidance studies including a doseresponse study (Schneider et al., 2006) using the procedures employed in the present study 
to produce both enhancement and impairment of retention under mild and intense stress, respectively (McGaugh et al., 1988; Schneider et al., 2009).

\subsection{Forced swim procedure}

The forced swim procedure (15 min in duration) was administered in a quiet, dimly lit room and consisted of placing rats in a cylindrical tank $(46-\mathrm{cm}$ tall $\times 20$-cm diameter) with water $\left(\sim 22{ }^{\circ} \mathrm{C}\right)$ filled to a depth of $30 \mathrm{~cm}$ (Porsolt et al., 1978; Schneider et al., 2009). The water depth of $30 \mathrm{~cm}$ forced the rats to swim or float without their tails touching the bottom of the tank.

The use of a compound stressor (i.e., foot-shock from passive-avoidance training followed by forced swim) to augment the intensity of stress exposure has been validated in previous neurochemical studies using activation of the hypothalamo-pituitary-adrenal (HPA) axis as a physiological index of stress intensity. In these studies, not only has swim stress been shown to elevate levels of plasma corticosterone (Kirby et al., 1995) and alter norepinephrine (NE) and opioid (dynorphin) levels in limbic nuclei, including the amygdala (Gotoh et al., 1998;

Jordan et al., 1994; Land et al., 2008), but the HPA response to swim stress has been shown to be augmented by prior exposure to shock (Christianson et al., 2003). Thus, exposure to forced swimming - with or without exposure to shock - not only meets the criteria of a stressor but produces neurochemical effects (particularly with respect to adrenergic and opioid action) consistent with a potential modulator of retention under highly stressful conditions.

\subsection{Experimental procedure}

Two experiments were conducted. The timeline for each experiment was as follows: rats underwent passive-avoidance training, in which they received a single foot-shock for stepping from a lighted to dark compartment, followed immediately by the experimental treatment (see below); $24 \mathrm{~h}$ later, a retention test was administered.

2.5.1. Passive-avoidance training-The training procedure consisted of the following: each rat was placed in the lighted compartment facing away from the sliding door. After $15 \mathrm{~s}$ the door was raised, the animal was allowed to step into the dark compartment, the door was lowered and shock $(0.5 \mathrm{~mA}, 0.5 \mathrm{~s})$ was delivered to the floor of the compartment. The animal remained in the dark compartment for $15 \mathrm{~s}$ and was then removed and immediately administered the experimental treatment. After each animal completed the trial the apparatus was cleaned.

2.5.2. Experimental treatment-In the first experiment, immediately after training, the animals were randomly assigned to one of two groups: swim and no swim. Animals in the swim group were exposed to forced swim stress ( $15 \mathrm{~min}$ in duration); animals in the no swim group were, in lieu of exposure to forced swim, placed in a quiet, dimly lit room (15 min in duration). Immediately thereafter each group was divided into two subgroups and was administered either the adrenergic blocker propranolol (Pro) or the vehicle yielding the following 4 groups: No Swim-Vehicle, No Swim-Pro, Swim-Vehicle and Swim-Pro.

In the second experiment, immediately after training, all animals were exposed to forced swim (15 min in duration) and then were randomly assigned to one of four groups - SwimVehicle, Swim-Pro, Swim-Nal and Swim-Pro + Nal - that received vehicle, propranolol (Pro), naloxone (Nal), or a combination of propranolol and naloxone, respectively.

2.5.3. Testing-The next day, animals received a retention test (identical to the training trial except shock was omitted and the experimental treatment was not administered) in 
which step-through latencies (STLs) served as the measure of retention (i.e., as STLs increased, retention was taken to increase). If STLs reached $600 \mathrm{~s}$, the trial was terminated.

\subsection{Statistical analysis}

Data were analyzed with one-way analyses of variance which, if statistically significant, were followed by protected- $t$ multiple comparisons tests. P values (two-tailed) of less than or equal to .05 were taken as statistically significant.

\section{Results}

The results of the first experiment, as shown in Fig. 1, indicate that propranolol administered immediately after exposure to the compound stressor (that is, foot-shock from the training procedure followed by forced swim) impaired retention: mean STLs in the Swim-Pro group $(97.0 \pm 50.8)$ were markedly lower than mean STLs in the Swim-Vehicle group (342.6 \pm 96.1) $(\mathrm{t}(14)=2.41, \mathrm{p}<0.05)$. On the other hand, propranolol administered in the absence of forced swim (i.e., when the stressor was foot-shock alone from the training procedure) did not impair retention: the difference in mean STLs between the No Swim-Pro group (334.8 \pm $83.1)$ and the No Swim-Vehicle group (368.2 \pm 76.4$)$ did not reach statistical significance $(\mathrm{t}(15)=0.29, \mathrm{p}=0.77)$. The finding that propranolol impaired retention only when administered after an intense stressor (specifically, after the combined stressor of foot-shock from passive-avoidance training followed by exposure to forced swim) is consistent with the hypothesis that propranolol's effectiveness in producing impairment of retention in the passive-avoidance task depends on the level of stress that accompanies its administration.

It can also be seen in Fig. 1 that forced swim per se, in the absence of propranolol, had no effect on retention: mean STLs in the Swim-Vehicle (342.6 \pm 96.1$)$ and No Swim-Vehicle $(368.2 \pm 76.4)$ groups did not differ significantly $(\mathrm{t}(13)=0.21, \mathrm{p}=0.84)$. The finding that forced swim had no effect on retention unless it was accompanied by adrenergic-receptor blockade suggests a "protective" function for the (unblocked) adrenergic-based modulatory system: when not blocked by propranolol, the adrenergic system prevents impairment of retention under conditions of intense stress.

The results of the second experiment, as shown in Fig. 2, reveal that separate administration of propranolol or naloxone immediately after exposure to the compound stressor (foot-shock followed by forced swim) impaired retention in the passive-avoidance procedure. In contrast, the combined administration of propranolol and naloxone produced no such impairment of retention. Specifically, mean STLs in the Swim-Nal $(69.7 \pm 38.5)$ and SwimPro group $(83.1 \pm 37.3)$ were significantly lower $(\mathrm{t}(16)=3.56$, $\mathrm{p}<0.01$ and $\mathrm{t}(16)=3.45$, $\mathrm{p}<0.01$, respectively) than mean STLs in the Swim-Vehicle group (349.2 \pm 72.9$)$. In contrast, mean STLs in the Swim-Pro + Nal group $(305.0 \pm 77.1)$ did not differ significantly $(\mathrm{t}(14)=$ $0.42, \mathrm{p}=0.68)$ from the Swim-Vehicle group (349.2 \pm 72.9$)$ but did differ $(\mathrm{t}(16)=2.90$, $\mathrm{p}<0.05$ and $\mathrm{t}(16)=2.75, \mathrm{p}<0.05$, respectively) from mean STLs in the Swim-Nal $(69.7 \pm$ $38.5)$ and the Swim-Pro groups $(83.1 \pm 37.3)$.

\section{Discussion}

The present findings demonstrate that a) $\beta$-adrenergic receptor blockade impairs retention when occurring immediately after intense, but not mild, stress in the passive-avoidance procedure, suggesting the presence of a protective, stress-dependent adrenergic-based modulation system, b) opioid-receptor blockade impairs retention when occurring immediately after intense stress in the passive-avoidance procedure, suggesting the presence of a protective, stress-dependent opioid-based modulation system, and c) simultaneous blockade of $\beta$-adrenergic and opioid receptors prevents impairment of retention when 
occurring immediately after exposure to intense stress in the passive-avoidance procedure, suggesting a non-additive interaction between the two modulation systems. Thus, these findings, taken together with earlier work (Schneider et al., 2009), not only indicate that the ability of $\beta$-adrenergic or opioid-receptor blockade to impair retention is critically dependent upon the intensity of stress, but also that the pharmacologically inactivated adrenergic-based and opioid-based memory-modulation systems interact to prevent impairment of retention.

One possible explanation for these results that is consistent with the literature is based on evidence indicating that stress affects memory via the combined and opposing action of inhibitory-opioid and excitatory-adrenergic modulation systems in brain sites such as the amygdala (Buffalari and Grace, 2007; Gallagher and Kapp, 1978; Gean et al., 1992; Huang et al., 1996; McIntyre and Wong, 1986). Accordingly in the present study, by singling out either the inhibitory-opioid or excitatory-adrenergic system alone through pharmacological blockade of the other, the unblocked system acts unopposed to impair retention: In the presence of adrenergic-receptor blockade, the unblocked inhibitory-opioid system "oversuppresses" brain sites (e.g., the amygdala) modulating memory; in the presence of opioidreceptor blockade, the unblocked excitatory-adrenergic system "over-activates" these brain sites. This would account for the impairment of retention produced by the separate administration of propranolol or naloxone. In contrast, neither over-suppression nor overactivation of modulation sites - and therefore no impairment of retention - should occur when a) both the inhibitory-opioid and excitatory-adrenergic systems are concurrently inactivated, or b) both systems are actively working in opposition to one another. These effects (or, more accurately, the lack thereof) on retention are precisely what occurred in the present study: the combined administration of propranolol and naloxone (perhaps by concurrently blocking both the excitatory-adrenergic and inhibitory-opioid modulation systems) failed to impair retention, as did the "administration" of swim-stress alone (perhaps by simultaneously activating the opposing modulation systems and thereby preventing overexcitation or over-suppression of brain sites modulating memory).

Combined and opposing action of inhibitory-opioid and excitatory-adrenergic modulation systems can also explain the enhancement of retention produced by naloxone under mildly stressful conditions (mild shock from passive-avoidance training in the absence of swimstress) seen in previous studies (Introini-Collison et al., 1989; McGaugh et al., 1988; Schneider et al., 2009). Specifically, the unblocked, endogenous opioid-based system, activated by mild stress, serves to limit enhancement of retention by opposing the simultaneous activation (as opposed to over-activation) of the excitatory adrenergic-based system. Accordingly, blockade of the inhibitory opioid-based system by naloxone under mildly stressful conditions enhances retention by reducing opposition to the excitatory adrenergic-based (facilitating) system. In this regard, previous studies have not only shown a) enhancement of retention by naloxone under mildly stressful conditions, but also, paralleling the results of the present study, b) amelioration of this enhancement (as opposed to impairment under intense stress in the present study) through concurrent blockade of the adrenergic-based system via intra-amygdala infusion of propranolol (Introini-Collison et al., 1989; McGaugh et al., 1988).

Given the ability of forced swim to reduce core body temperature (Porsolt et al., 1979), one might propose that the effects of propranolol and naloxone on retention were influenced by hypothermia. Indeed, previous studies have shown that forced swim (15-min) in $20-25^{\circ} \mathrm{C}$ water can reduce rat body temperature by $5-10^{\circ} \mathrm{C}$ (Drugan et al., 2005; Porsolt et al., 1979); this magnitude of hypothermia can impair clearance rates of a number of drugs (van den Broek et al., 2010), including propranolol (McAllister and Tan, 1980), owing to decreased activity of liver enzymes. 
Although impairment of drug clearance may have occurred in the present study, it did not appear to have a significant behavioral effect: the effect of the drugs in animals exposed to forced swim was not amplified to a level expected were drug clearance significantly impaired, that is, were drug potency significantly augmented by hypothermia. For example, administration of propranolol $(10 \mathrm{mg} / \mathrm{kg}$ ) after forced swim did not produce the toxic effects (e.g., sedation and writhing) typically associated with administration of higher doses of the agent $(15 \mathrm{mg} / \mathrm{kg}$ ) seen in previous studies in the absence of forced swim (Pontecorvo et al., 1991). Moreover, when administered separately at doses twice as high as those shown in the present study to impair retention after forced swim, propranolol and naloxone fail to impair retention in the absence of forced swim (Beatty and Rush, 1983; Messing et al., 1979). Thus, it seems reasonable to conclude that the behavioral effects observed in the present study were not influenced to an appreciable extent by hypothermia-augmented drug potency.

In view of the relative importance given to the role of the adrenergic-based system in mediating the effect of stress on memory modulation (Galvez et al., 1996; Quirarte et al., 1998), it is perhaps surprising that only one other study has demonstrated an impairing effect of systemic blockade of the adrenergic system on retention in the passive-avoidance procedure (Przybyslawski et al., 1999). One reason - the one that distinguishes the present study - may be methodology: the combination of passive-avoidance training and forced swim.

On the other hand, although the impairing effect of systemically administered propranolol in the passive-avoidance procedure is relatively new, the finding of impairment of retention by propranolol in general is not. Specifically, in addition to impairing retention when administered systemically in the present study or the water maze (Cahill et al., 2000), local infusion of propranolol into the amygdala impairs retention both in the passive-avoidance procedure (Gallagher et al., 1977; Lennartz et al., 1996) as well as an object learning task (Roozendaal et al., 2008). These findings, particularly with regard to object learning wherein the animals are not under intense stress prior to administration of the drug, suggest that propranolol's effectiveness in producing impairment depends not only on the level of stress (as shown in the present study), but also on the mode of administration (as shown in the local administration studies).

One brain site potentially mediating the effect of blockade of the adrenergic and/or opioid modulation systems on retention in the present study, as suggested by the local infusion studies, is the amygdala. The amygdala is rich in all major subtypes of opioid (Mansour et al., 1994) and adrenergic (U'Prichard et al., 1980) receptors, and opioid (dynorphin) and NE release in the amygdala are increased by stress (Galvez et al., 1996; Hatfield et al., 1999; Land et al., 2008). Further, whereas $\beta$-adrenergic agonists increase both neuronal activity (Buffalari and Grace, 2007; McIntyre and Wong, 1986) and excitatory neurotransmission in the amygdala (Ferry et al., 1997; Gean et al., 1992; Huang et al., 1996) and, at all but the highest doses [owing to an inverted-U dose-response function (Gold, 2006)], enhance retention in the passive-avoidance procedure, opioid agonists decrease amygdala activity and impair retention in the passive-avoidance procedure (Gallagher and Kapp, 1978; Quirarte et al., 1998). Of course, before conclusions can be drawn with regard to the involvement of specific brain sites in mediating the effect of swim stress on memory modulation, local administration of adrenergic and opioid-receptor antagonists into the brain, paralleling the systemic administration studies presented herein, are necessary.

Both adrenergic and opioid-receptor antagonists have been proposed as potential therapies for posttraumatic stress disorder (Albucher and Liberzon, 2002; Pitman et al., 2002), a disorder characterized by persistent and intrusive negative memories of a stressful event. The present results support the efficacy of the two receptor antagonists in attenuating 
pathological memories but caution that their effectiveness may be stress-dependent and enhanced by single, rather than simultaneous, administration.

In conclusion, the present results not only demonstrate the stress-dependent effects of pharmacological blockade of the adrenergic and opioid systems on memory modulation, but also provide a framework in which to view the protective role played by simultaneous activation or inactivation of endogenous excitatory-adrenergic and inhibitory-opioid modulation systems in mediating the effect of stress on memory.

\section{Acknowledgments}

This work was supported by a grant from the Howard Hughes Medical Institute to Swarthmore College and NIH grant DA 20126 to L. Kirby. Luis Hernandez expertly assisted in conducting the experiments. Dr. E. Carr Everbach, Department of Engineering, Swarthmore College, expertly assisted in programming the behavioral equipment.

\section{Abbreviations}

$\begin{array}{ll}\text { HPA } & \text { hypothalamo-pituitary-adrenal } \\ \text { Nal } & \text { naloxone } \\ \text { NE } & \text { norepinephrine } \\ \text { Pro } & \text { propranolol } \\ \text { STL } & \text { step-through latency } \\ \text { Veh } & \text { vehicle }\end{array}$

\section{References}

Albucher RC, Liberzon I. Psychopharmacological treatment in PTSD: a critical review. J Psychiatr Res. 2002; 36:355-367. [PubMed: 12393304]

Beatty WW, Rush JR. Spatial working memory in rats: effects of monoaminergic antagonists. Pharmacol Biochem Behav. 1983; 18:7-12. [PubMed: 6828539]

Buffalari DM, Grace AA. Noradrenergic modulation of basolateral amygdala neuronal activity: opposing influences of alpha-2 and beta receptor activation. J Neurosci. 2007; 27:12358-12366. [PubMed: 17989300]

Cahill L, Pham CA, Setlow B. Impaired memory consolidation in rats produced with beta-adrenergic blockade. Neurobiol Learn Mem. 2000; 74:259-266. [PubMed: 11031131]

Christianson JP, Townson DH, Drugan RC. Comparison of intermittent shock and intermittent cold water swim stress on corticosterone and TNF-alpha at two time points after a forced swim test. Soc Neurosci Abs. 2003; 756.5

Decker MW, Gill TM, McGaugh JL. Concurrent muscarinic and beta-adrenergic blockade in rats impairs place-learning in a water maze and retention of inhibitory avoidance. Brain Res. 1990; 513:81-85. [PubMed: 2161697]

Drugan RC, Eren S, Hazi A, Silva J, Christianson JP, Kent S. Impact of water temperature and stressor controllability on swim stress-induced changes in body temperature, serum corticosterone, and immobility in rats. Pharmacol Biochem Behav. 2005; 82:397-403. [PubMed: 16236352]

Ferry B, Magistretti PJ, Pralong E. Noradrenaline modulates glutamate-mediated neurotransmission in the rat basolateral amygdala in vitro. Eur J Neurosci. 1997; 9:1356-1364. [PubMed: 9240393]

Ferry B, McGaugh JL. Involvement of basolateral amygdala alpha2-adrenoceptors in modulating consolidation of inhibitory avoidance memory. Learn Mem. 2008; 15:238-243. [PubMed: 18391184] 
Ferry B, Roozendaal B, McGaugh JL. Involvement of alpha1-adrenoceptors in the basolateral amygdala in modulation of memory storage. Eur J Pharmacol. 1999; 372:9-16. [PubMed: 10374709]

Gallagher M, Kapp BS. Manipulation of opiate activity in the amygdala alters memory processes. Life Sci. 1978; 23:1973-1977. [PubMed: 214656]

Gallagher M, Kapp BS, Musty RE, Driscoll PA. Memory formation: evidence for a specific neurochemical system in the amygdala. Science. 1977; 198:423-425. [PubMed: 20664]

Galvez R, Mesches MH, McGaugh JL. Norepinephrine release in the amygdala in response to footshock stimulation. Neurobiol Learn Mem. 1996; 66:253-257. [PubMed: 8946419]

Gean PW, Huang CC, Lin JH, Tsai JJ. Sustained enhancement of NMDA receptormediated synaptic potential by isoproterenol in rat amygdalar slices. Brain Res. 1992; 594:331-334. [PubMed: 1360324]

Gold PE. The many faces of amnesia. Learn Mem. 2006; 13:506-514. [PubMed: 17015847]

Gotoh M, Tajima T, Suzuki Y, Ikari H, Iguchi A, Kakumu S, Hirooka Y. Swimming stress that causes hyperglycemia increases in vivo release of noradrenaline, but not acetylcholine, from the hypothalamus of conscious rats. Brain Res. 1998; 780:74-79. [PubMed: 9473595]

Hatfield T, Spanis C, McGaugh JL. Response of amygdalar norepinephrine to footshock and GABAergic drugs using in vivo microdialysis and HPLC. Brain Res. 1999; 835:340-345. [PubMed: 10415392]

Huang CC, Hsu KS, Gean PW. Isoproterenol potentiates synaptic transmission primarily by enhancing presynaptic calcium influx via P- and/or Q-type calcium channels in the rat amygdala. J Neurosci. 1996; 16:1026-1033. [PubMed: 8558230]

Introini-Collison IB, Nagahara AH, McGaugh JL. Memory enhancement with intra-amygdala posttraining naloxone is blocked by concurrent administration of propranolol. Brain Res. 1989; 476:94-101. [PubMed: 2914216]

Jordan S, Kramer GL, Zukas PK, Petty F. Previous stress increases in vivo biogenic amine response to swim stress. Neurochem Res. 1994; 19:1521-1525. [PubMed: 7877723]

Kirby LG, Allen AR, Lucki I. Regional differences in the effects of forced swimming on extracellular levels of 5-hydroxytryptamine and 5-hydroxyindoleacetic acid. Brain Res. 1995; 682:189-196. [PubMed: 7552310]

Land BB, Bruchas MR, Lemos JC, Xu M, Melief EJ, Chavkin C. The dysphoric component of stress is encoded by activation of the dynorphin kappa-opioid system. J Neurosci. 2008; 28:407-414. [PubMed: 18184783]

Lennartz RC, Hellems KL, Mook ER, Gold PE. Inhibitory avoidance impairments induced by intraamygdala propranolol are reversed by glutamate but not glucose. Behav Neurosci. 1996; 110:1033-1039. [PubMed: 8919006]

Liang KC, Juler RG, McGaugh JL. Modulating effects of posttraining epinephrine on memory: involvement of the amygdala noradrenergic system. Brain Res. 1986; 368:125-133. [PubMed: 3955350]

Liang KC, McGaugh JL, Yao HY. Involvement of amygdala pathways in the influence of post-training intra-amygdala norepinephrine and peripheral epinephrine on memory storage. Brain Res. 1990; 508:225-233. [PubMed: 2306613]

Mabry TR, Gold PE, McCarty R. Age-related changes in plasma catecholamine responses to acute swim stress. Neurobiol Learn Mem. 1995; 63:260-268. [PubMed: 7670839]

Mansour A, Fox CA, Burke S, Meng F, Thompson RC, Akil H, Watson SJ. Mu, delta, and kappa opioid receptor mRNA expression in the rat CNS: an in situ hybridization study. J Comp Neurol. 1994; 350:412-438. [PubMed: 7884049]

McAllister RG Jr, Tan TG. Effect of hypothermia on drug metabolism. In vitro studies with propranolol and verapamil. Pharmacology. 1980; 20:95-100. [PubMed: 7384193]

McGaugh JL. Involvement of hormonal and neuromodulatory systems in the regulation of memory storage. Annu Rev Neurosci. 1989; 12:255-287. [PubMed: 2564756]

McGaugh JL, Introini-Collison IB, Nagahara AH. Memory-enhancing effects of posttraining naloxone: involvement of beta-noradrenergic influences in the amygdaloid complex. Brain Res. 1988; 446:37-49. [PubMed: 2836028] 
McIntyre DC, Wong RK. Cellular and synaptic properties of amygdala-kindled pyriform cortex in vitro. J Neurophysiol. 1986; 55:1295-1307. [PubMed: 3016209]

Messing RB, Jensen RA, Martinez JL Jr, Spiehler VR, Vasquez BJ, Soumireu-Mourat B, Liang KC, McGaugh JL. Naloxone enhancement of memory. Behav Neural Biol. 1979; 27:266-275. [PubMed: 518457]

Pitman RK, Sanders KM, Zusman RM, Healy AR, Cheema F, Lasko NB, Cahill L, Orr SP. Pilot study of secondary prevention of posttraumatic stress disorder with propranolol. Biol Psychiatry. 2002; 51:189-192. [PubMed: 11822998]

Pontecorvo MJ, Clissold DB, White MF, Ferkany JW. N-methyl-D-aspartate antagonists and working memory performance: comparison with the effects of scopolamine, propranolol, diazepam, and phenylisopropyladenosine. Behav Neurosci. 1991; 105:521-535. [PubMed: 1657031]

Porsolt RD, Anton G, Blavet N, Jalfre M. Behavioural despair in rats: a new model sensitive to antidepressant treatments. Eur J Pharmacol. 1978; 47:379-391. [PubMed: 204499]

Porsolt RD, Deniel M, Jalfre M. Forced swimming in rats: hypothermia, immobility and the effects of imipramine. Eur J Pharmacol. 1979; 57:431-436. [PubMed: 258612]

Przybyslawski J, Roullet P, Sara SJ. Attenuation of emotional and nonemotional memories after their reactivation: role of beta adrenergic receptors. J Neurosci. 1999; 19:6623-6628. [PubMed: 10414990]

Quirarte GL, Galvez R, Roozendaal B, McGaugh JL. Norepinephrine release in the amygdala in response to footshock and opioid peptidergic drugs. Brain Res. 1998; 808:134-140. [PubMed: 9767150]

Roozendaal B, Castello NA, Vedana G, Barsegyan A, McGaugh JL. Noradrenergic activation of the basolateral amygdala modulates consolidation of object recognition memory. Neurobiol Learn Mem. 2008; 90:576-579. [PubMed: 18657626]

Saha N, Datta H, Sharma PL. Effects of morphine on memory: interactions with naloxone, propranolol and haloperidol. Pharmacology. 1991; 42:10-14. [PubMed: 2057517]

Schneider AM, Simson PE, Spiller K, Adelstein J, Vacharat A, Short KR, Kirby LG. Stress-dependent enhancement and impairment of retention by naloxone: evidence for an endogenous opioid-based modulatory system protective of memory. Behav Brain Res. 2009; 205:290-293. [PubMed: 19523491]

Schneider AM, Spiller K, Adelstein J, Vacharat A, Ruff A, Kirby LG, Short K, Simson PE. Opioid receptor blockade interacts with swim stress to impair retention: evidence for a stress-activated endogenous opioid system protective of memory. Soc Neurosci Abs. 2006; 811.9

U'Prichard DC, Reisine TD, Mason ST, Fibiger HC, Yamamura HI. Modulation of rat brain alpha- and beta-adrenergic receptor populations by lesion of the dorsal noradrenergic bundle. Brain Res. 1980; 187:143-154. [PubMed: 6244065]

van den Broek MP, Groenendaal F, Egberts AC, Rademaker CM. Effects of hypothermia on pharmacokinetics and pharmacodynamics: a systematic review of preclinical and clinical studies. Clin Pharmacokinet. 2010; 49:277-294. [PubMed: 20384391] 


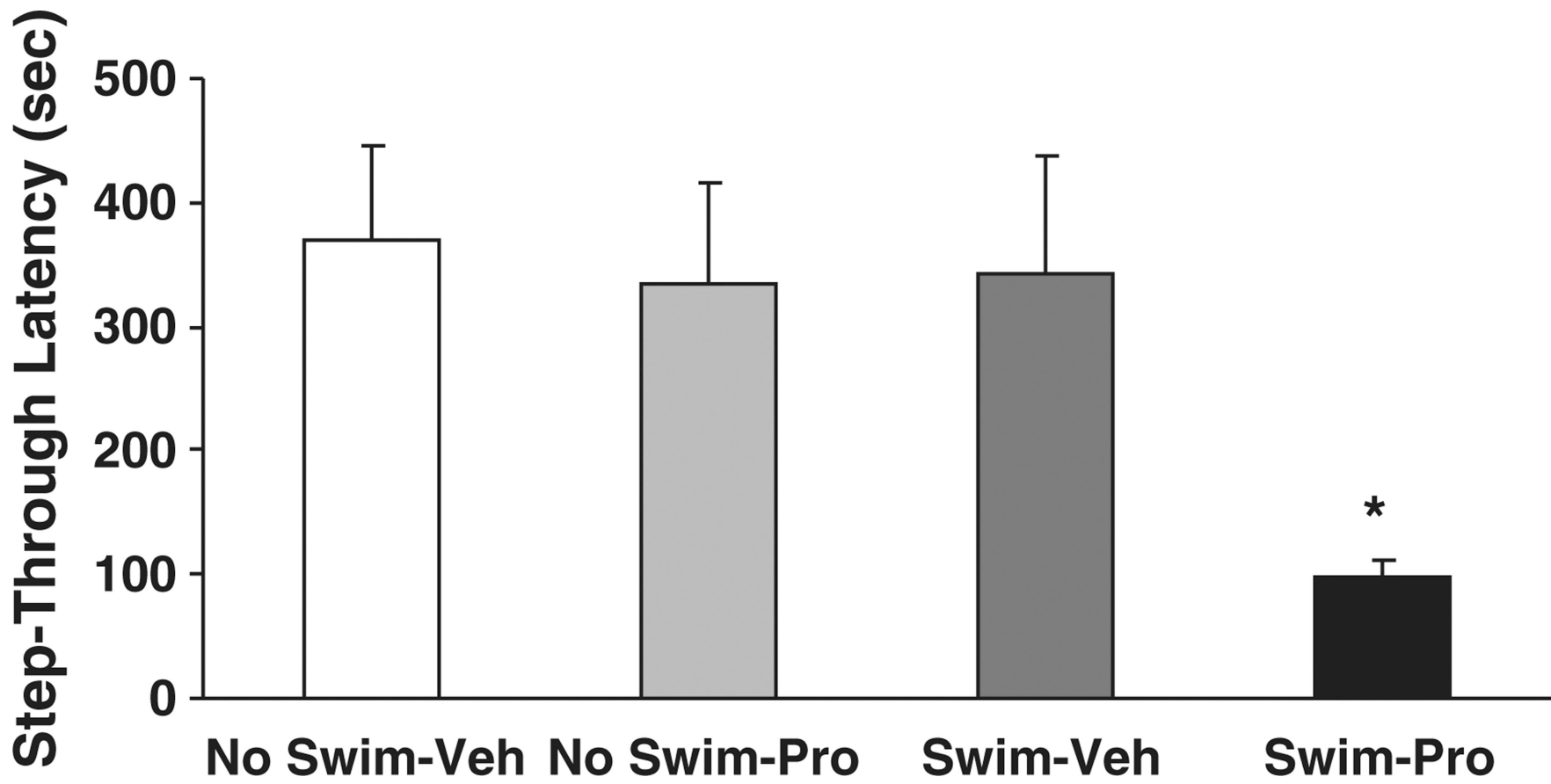

Fig. 1.

Propranolol impairs retention in the presence but not in the absence of swim stress. Stepthrough latency (mean \pm SEM) in seconds on the test trial for the No Swim-Vehicle group (n = 8), No Swim-Pro group ( $\mathrm{n}=9)$, Swim-Vehicle group $(\mathrm{n}=7)$, and Swim-Pro group $(\mathrm{n}=9)$. ${ }^{*} \mathrm{p}<0.05$ compared with the corresponding vehicle group. P-values shown are for significant protected- $t$ tests following one-way ANOVA; $\mathrm{F}(3,29)=2.89, \mathrm{p}=0.05$. Pro-propranolol and Veh-vehicle. 


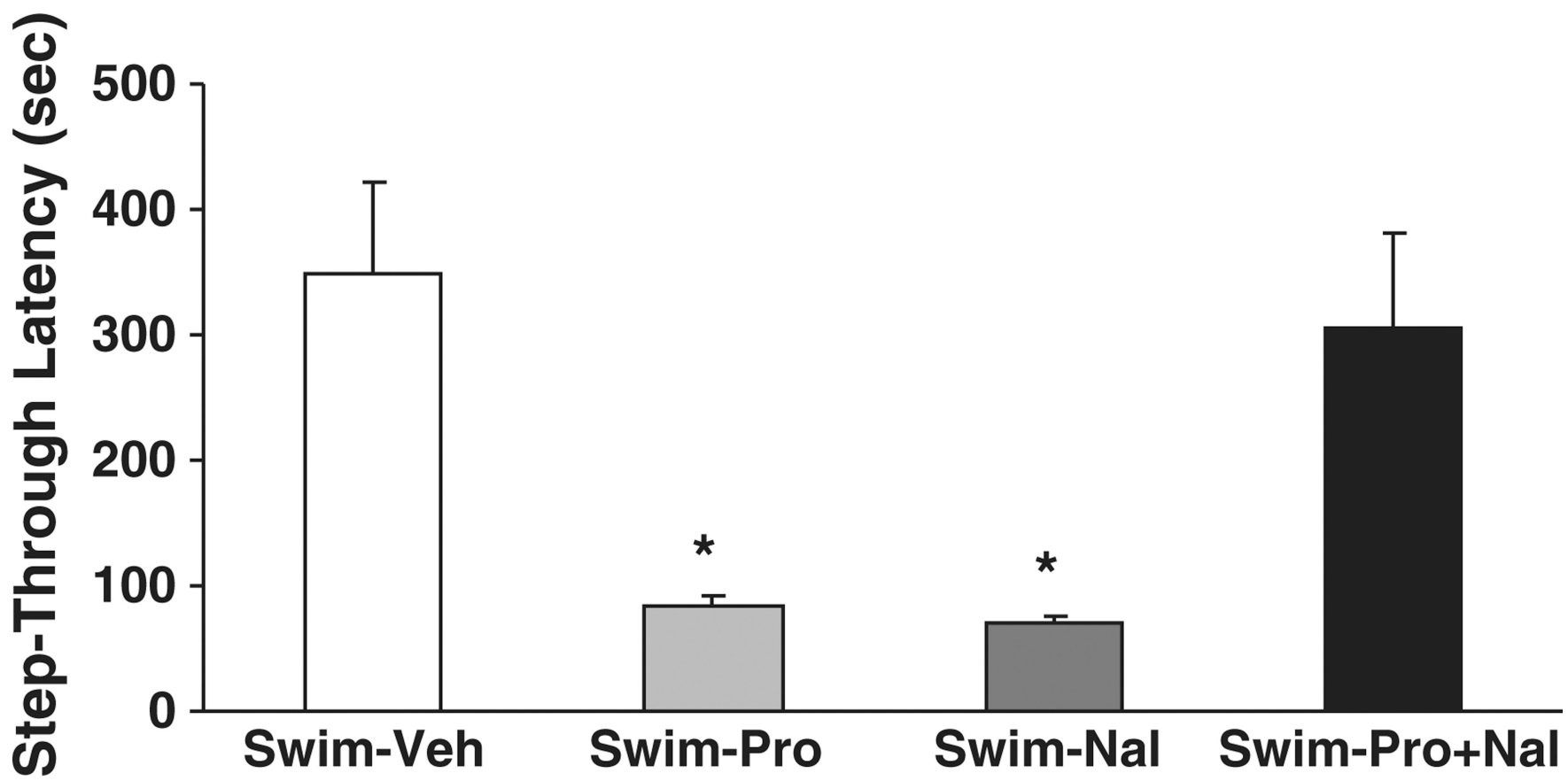

Fig. 2.

Propranolol and naloxone each impair retention in the presence of swim stress but not when administered in combination. Step-through latency (mean \pm SEM) in seconds on the test trial for the Swim-Vehicle group ( $\mathrm{n}=8)$, Swim-Pro group $(\mathrm{n}=10)$, Swim-Nal group $(\mathrm{n}=10)$, and Swim-Pro + Nal group $(\mathrm{n}=8) .{ }^{*} \mathrm{p}<0.01$ compared with the corresponding Swim-Vehicle group and $\mathrm{p}<0.05$ compared to the Swim-Pro + Nal group. P-values shown are for significant protected-t tests following one-way ANOVA; F $(3,32)=6.80$, $\mathrm{p}<0.01$. Propropranolol, Nal—naloxone and Veh—vehicle. 